From diaspora to ethnoscapes: diversity and belongingness in transnational migrations

\title{
Da diáspora às etnopaisagens: diversidade e pertencimento nas migrações transnacionais
}

\author{
SOFIA CAVALCANTI ZANFORLIN* \\ Universidade Federal de Pernambuco, Graduate Program in Communication. Recife - PE, Brazil
}

\begin{abstract}
The discussion in this article is associated with the experience of field researches in four Brazilian cities, Brasília, São Paulo, Rio de Janeiro and Manaus, between 2011 and 2015, having as guideline the negotiations for belongingness performed by contemporary immigrant communities in Brazil. From questions made by Stuart Hall in "Thinking the diaspora", mainly the question of the Caribbean diaspora, we discuss the new belongingness negotiation and the imaginary desire to the return to the land left. Exploring this tension is the objective of this article, bringing the debate to the new immigrant communities in Brazil.
\end{abstract}

Keywords: Migration, diaspora, ethnoscape, belongingness

\section{RESUMO}

A discussão neste artigo se articula a experiências de pesquisas de campo realizadas em quatro cidades brasileiras, Brasília, São Paulo, Rio de Janeiro e Manaus, entre 2011 e 2015, tendo como fio condutor as negociações por pertencimento realizadas pelas comunidades de imigrantes contemporâneas no Brasil. A partir de questões levantadas por Stuart Hall em "Pensando a diáspora", principalmente a questão da diáspora caribenha, discutimos a negociação dos novos pertencimentos e o desejo imaginário ao retorno à terra deixada. Explorar essa tensão é o objetivo deste artigo, trazendo o debate para as novas comunidades de imigrantes no Brasil.

Palavras-chave: Migração, diáspora, etnopaisagem, pertencimento

* Professor of the Graduation Program in Communication Sciences of Universidade Católica de Brasília [Catholic University of Brasilia. PHD in Communication and Culture from Universidade Federal do Rio de Janeiro [Federal University of Rio de Janeiro]. Author of Etnopaisajes en las metrópolis brasileñas: migración, comunicación y sentimiento de pertenencia (Barcelona: Editoral UOC, 2016). Orcid: http://orcid. org/0000-0003-4030-1329 E-mail: szanforlin@gmail. com 


\section{From diaspora to ethnoscapes: diversity and belongingness in transnational migrations}

\section{INTRODUCTION}

T $\mathrm{n}$ "Thinking the diaspora: Home-Thoughts from abroad" (2003), Stuart Hall asks: "What does the diaspora experience do to our models of cultural identity? How are we to conceptualize or imagine identity, difference and belongingness, after diaspora?" (Ibid.: 28). At the same time, he points out that each diaspora "carries with it the promise of redemptive return" (Ibid.). It is in this tension, between new belongingness and the desire to return to the land left, that Hall discusses the diaspora question, from the Caribbean experience. Exploring this tension is the objective of this article, bringing the debate to the new immigrant communities in Brazil.

We problematized the diaspora concept from three authors: Robin Cohen (2008), Arjun Appadurai (2004) and Stuart Hall (1993, 2000, 2003, 2013). They are contemporary readings of a concept whose origin dates back to the Jewish experience. The conceptual discussion in this article is associated with the experience of field researches in four Brazilian cities, Brasília, São Paulo, Rio de Janeiro and Manaus, between 2011 and 2015, having as guideline the negotiations for belongingness performed by contemporary immigrant communities in Brazil. The current Brazilian migrant question increases in the midst of indefiniteness about the anachrony of the migratory legislation, dated 1980, whose law is based more on the defense guaranty of the national territory to the "threats from foreign presence." Thus, the migration in contemporary Brazil occurs by the economic migrant, ergo subject to being stigmatized as illegal, refugee or, most of times, refuge solicitor. The fundamental point here is the analysis of the immigrants' narratives of Angolan, Congolese, Haitian, Ghanaian, Bengali and Pakistani communities from the researches carried out by the author. More than a comparison between the mentioned groups, and beyond a specific case study, the important is to problematize the aspects related to the diaspora concept and confront it in the light of the elements that compound the scene of the transnational migrations in the present.

We still reflect on Appadurai's conceptualization (2004) about the diaspora public spheres, responsible, according to the author, for the formation of ethnoscapes in global cities. Thereby, the ethnoscapes reconfigure the current context composed of displacement of tourists, migrants, refugees, exiles, workers and other groups and individuals in movement. That is the way that the diasporas establish new parameters on what constitutes the contemporary real, reconfigure the identity experience and the new belongingnesses. 


\section{THE CARIBBEAN DIASPORA BY STUART HALL}

For Stuart Hall, the discussion around the diaspora theme occurs by the tension between the maintenance of belongingness to the origin land and the new identities that "become multiple" within the diaspora situation. Hall, who identified himself as a diasporic intellectual, Caribbean person from Jamaica, living in England, seems to talk to himself, and, obviously, to his personal history, by working on these questions in the article "Thinking the diaspora" (Hall, 2003). "And how are we to think of national identity and 'belongingness' in the Caribbean in the light of this diaspora experience?”(Ibid.: 26), he provokes.

Perhaps what Hall suggests is that the diasporic condition traverses the Caribbean history in a constitutive way. We certainly can allude to other places and peoples that have their identities constituted from the diaspora, and then we shall reach the Jewish experience, whose term may be understood as primordial synonym of this definition. Hall remembers that the Jewish diaspora analogy of the Old Testament may be recognized in the movement of the Jah People, from Jamaica, whose "New World narrative of freedom, hope and redemption [...] has provided every black New World liberatory discourse with its governing metaphor" (Ibid.: 29). However, beyond authorial or conceptual questions, thinking the Caribbean identity, as proposed by Hall, is to think of a place marked by the experience of peoples that come in diaspora, and even are doubly diasporic, when migrating from Caribbean to the European metropolitan centers. During an interview, the author problematizes the diasporic personal experience.

I am not at home in either of these two places, which I suppose is why I emphasize my, well, I suppose Homi Bhabha would call it my in-betweenness. That is why I am interested in the diasporas, why I am interested in why hybridities, why I am interested in the in-betweenness and then what constitutes a sense of home to which you can never actually return. (Hall, 2013: 197)

Nevertheless, in another text, Hall points out that the migrant's dispersed and fragmented condition becomes, in postmodernism, a more stabilizing condition within the contemporary experience. The fragmentation, the in-betweenness, comes to be as being at home, being comfortable about not having a center (Hall, 1993). 


\section{From diaspora to ethnoscapes: diversity and belongingness in transnational migrations}

The Caribbean diaspora, beyond the historical peculiarities of the Caribbean countries also synthesizes, roughly, their similarities: lands that had their originating indigenous populations assimilated or annihilated by genocide, lands that were usurped to serve as plantation and exploitation for the Spanish, French and English colonies, lands that served as receipt and disposal of slaves. Exploitation and suffering are marks in the history of the Caribbean countries: "Poverty, underdevelopment, the lack of opportunities - the legacies of Emperor everywhere - may force people to migrate. Bringing about the scattering - the dispersal. But each dissemination carries with it the promise of redemptive return" (Hall, 2003: 28), and this hope, according to him, is condensed as a foundational myth inscribed in the Caribbean imaginary. However, will the return occur? In "Minimal selves" (1993), Hall affirms that the immigration is a journey without return, and indicates motives almost psychoanalytic to construct the purposes for which one migrates: "The truth is, I am here because it's where my family is not. I really came here to get away from my mother. Isn't that the universal story of life?"(Ibid.: 135). In this way, he chooses to work the relationship between migration and subjective construction as the apex of the constitution of subjectivity through the difference. It was as a diasporic Jamaican that his experience of migrant in England was constituted and, in turn, in his recognition as black.

The myth of redemptive return can be identified in the reports from the Haitian migrants interviewed by the author in the field activities in Manaus and Brasilia in research performed in the first half of 2013. Haiti remains in the migrants' imagination as their home, point of origin of their identity and their primordial affective bonds. Is Brazil their transitional place, although this time is a whole life? Is this the time for betting, for preparation to return? In reports from migrant men, a facet of Brazilian migration whose majority is male, it is possible to identify two tendencies, if one is here to work, it is possible to bring wife and children and still be together preparing themselves for the return, with the family strengthened and developed; or, if to study and, having received training, one would meet the material conditions to effect the return and work for the development of his country, Haiti. Will the return occur? Or does it work only as a condition of the Haitian diasporic identity? Perhaps this question does not have a prompt answer, once "Foundational myths are, by definition, transhistorical [...] Their redemptive power lies in the future, which is yet to come" (Ibid.: 29). This future may last a whole life. The important is not to underestimate the power of the myths when "circling 
back to the restoration of its originary moment, healing all rupture, repairing every violent breach through this return" (Ibid.: 29).

The myth of the return has not emerged in African migrants' reports, in the experience limited to the mentioned researches, what would justify the breakout of the myth power by the reality of the bonds established in the new land. Both the Angolan migrants, established in Brazil for more than twenty years (Zanforlin, 2011), and the migrants from Congo, whose majority have lived in Brazil for less than five years, and even immigrants newly arrived, no longer express the return discourse. In another research initiated in the first half of 2014, the African migrants' reports, this time coming from Ghana and Senegal, and established in the Federal District, do not sustain the return as an irrevocable promise either. In spite of the peculiarities of the mentioned flows, the Angolans affected by the civil war in their country, the Ghanaian and Senegalese migrants identified by the seal of economic migrants.

Their attention is focused on the conquest of the new home, that is Brazil, but that may be another country. Maybe the foundational myth of the African imaginary is what is closer to Hall's argument that the migration is a way without return: the African history is rewritten through the culture to be creolized in Caribbean, hybrid in America, to be politically challenged in Europe: "We know this term 'Africa' is, in any event, a modern construction, referring to a variety of peoples, tribes, cultures and languages whose principal common point of origin lay in the confluence of the slave trade", as Hall highlights (2003: 31). Thus, the freedom and the accomplishment of the autonomy are still in the point of origin of an African identity.

The Caribbean, in turn, as Hall points out, is the example of a modern diaspora, with its culture impelled by a diasporic aesthetic, where the hybridism and the mix are marks permeated by the cultures and by the power relations. And where Africa presents itself as the "significant, the metaphor", the question is "it has been a matter of interpreting 'Africa', rereading 'Africa', or what 'Africa' could mean to us now, after diaspora" (Ibid.: 40). Therefore, Hall promotes a notion of the concept of "diaspora" much more focused on the Derridian definition of différance, which does not work through "binaries, veiled boundaries that do not finally separate but double up as places of passage, and meanings that are positional and relational, always on the slide along a spectrum without end or beginning" (Ibid.: 33). For Hall, the closed concept of diaspora would be supported, 


\section{From diaspora to ethnoscapes: diversity and belongingness in transnational migrations}

thus, by a binary conception of difference, impossible to be worked in the Caribbean reality.

\section{USES AND ABUSES OF THE CONCEPTION OF DIASPORA}

The typical definition of the conception of diaspora may be synthesized as being "the traumatic dispersal from original homeland of a forcibly dispersed group." (Cohen, 2008: 4), and it is necessary, according to Robin Cohen, to have its understanding updated. Cohen recurs to several authors who have studied the theme and gathers these discussions in Global Diasporas (2008). According to Cohen, Safran, one of the most well-known researchers on this theme, considers the Jewish diaspora as the starting point for the term definition, and, still, localizes the fundamental characteristic of the diaspora in the tension between the land left and the idealized return: for Safran, members of a diaspora keep in their memories the original land, they idealize the land of ancestry, where compromise themselves with the restoration of the original land, and keep relating to this land in several ways. (Ibid.)

In this thought, the maintenance of an imaginary is a condition focused on the symbolic construction of the land left in the past, which should be re-enchanted by generations of people from a common origin, and a source of an imagined force to resist and stand before the pressure from the place to where one went. These elements are fundamental for the observation of a common narrative in a diasporic group or community, under the risk of not resisting to these pressures. The Jewish diaspora is the main example for a conceptual definition, once this narrative started in A.D. 586 and still renovates nowadays on media texts as a justification, for instance, for the Israel State's militarist actions. In any case, the tension between the expulsion and the idealized return seems to be the line that contours the concept in a multiplicity of studies.

The Jewish diaspora, thus, would mark the first phase of the theme studies. The second phase would start from the 1980s, and according to Cohen, would inaugurate a metaphoric use of the term, for different categories, including expatriates, outcasts, political refugees, immigrants, ethnic and religious minorities, where one can note a distinct use of the initial milestone, less connected to the origin land, and more focused on designating a variety of clusters of diasporas. The third phase, from the half of the $1990 \mathrm{~s}$, is marked by the second phase conceptual review and criticism by scholars of the theme. The argument 
is that, in the postmodernity, the identities become deterritorialized, constructed and deconstructed with more flexibility. Then, concepts such as the diaspora should be radically amplified to meet these transformations. The fourth phase, at the turn of the 2000s, initiates the current phase in which the concept goes through a moment of review and consolidation once, for some scholars, the concept of diaspora would be in the process of becoming empty from its descriptive and analytical force due to the proliferation of its use, a diaspora of the very term diaspora.

However, we would like to present in this article the main points that delineate the concept, as well as the main groups whose diasporic experience compound their identities, from the empiric experience of the research. Thus, besides the diaspora conceptualization presented, we need, alternatively or additionally, to expand the notion of origin land to include the collective memory and the myths around the ancestry land, that comprehend: a collective commitment in the maintenance of the place, through restoration, development or even its creation; a collective desire of return, a strong ethnic identity supported over time on which a common history is based, the cultural transmission, the religious heritage based on the belief in a shared faith, and an empathy and co-responsibility sense among members who live in different countries, where the notion on origin land comprehend a more fluid notion of home and belongingness. This path would situate the concept of diaspora closer to the contemporary reality and would promote a distinction in the term use.

To finalize, we present a representative panorama of diaspora situations, as synthesized by the discussions developed in Global Diasporas (2008). We emphasize four types: 1) diaspora of victims, in which the Jews, Africans, Armenians are classically highlighted, being possible to include the Irish people and Palestinians; 2) the labor diaspora, in which the Indians, the Chinese and the Japanese appear (maybe this is the most elastic category in Cohen's classification, in which one can associate the labor exploitations to Latin American migrants in the United States, and, in Brazil, the Bolivians and the clandestine sewing industry);3) the imperial diaspora, in which the $20^{\text {th }}$ century colonial industry is highlighted; and 4) the deterritorialized diaspora, in which Cohen situates the Persians, the Gypsies and the Caribbeans. In relation to the Caribbean diaspora, Cohen shares Hall's vision, appealing to quotes from the latter, by talking about the need of a multifaceted look for the characterization of this group, once the perception of the notion of origin land, or homeland, by the Caribbean 


\section{From diaspora to ethnoscapes: diversity and belongingness in transnational migrations}

peoples, should be as "fluid, vibrant and frequently changing set of cultural interactions" (Cohen, 2008: 123). Or, as Hall mentioned: "The diaspora experience as I intend it here is defined, not by essence or purity, but by the recognition of a necessary heterogeneity and diversity; by a conception of 'identity' which lives with and through, not despite, difference; by hybridity". (Hall, 1990: 235)

\section{PUBLIC SPHERES OF DIASPORA: THE ETHNOSCAPES}

Although one tries to define the concept of diaspora, we should remember that it is something in movement, subject, then, to new forms and definitions. Diasporas are in frequent formation and reformation, they may be done and redone, much more in the global era, where one confirms the need to study them without, however, conceiving them in fixed formats.

Cohen (2008) emphasizes four aspects that stress the notion of diaspora in contemporaneity: the economy globalization, which allows great connectivity; the expansion of companies and the growth of new professions and labor exchange, creating new opportunities of diaspora; the international migrations, which encourage new models of contracting, intermittent stays, family visits, allowing the transnational transit and relativizing the adoption of a single citizenship; the development of a cosmopolitan sensitivity, in which in many global cities it is possible to identify the intensification of transactions and interactions between people from different places of the world; and, finally, the religious revival as focus of social cohesion, via a dispersion, a new kind of peregrination, coming from the multifaceted development of religious globally connected in a complex diasporic phenomenon, considering the dissemination of the neo-pentecostal churches. (Ibid.: 141)

Another author that is added to this argument is Appadurai, who constructs "a theory of rupture that takes media and migration as its two major, and interconnected, diacritics" (2004: 15). These two movements would have direct effect on the constitution of the imagination, the latter being reflected, in its turn, in the constitution of the contemporary subjectivity. Thus, the author put the "rapid flow of mass-mediated images, scripts and sensations" with the question of mass migrations, as fundamental for the construction of "a new order of instability in the production of modern subjectivities" (Ibid.). In this perspective, the electronic communication would represent the total existence of the experience of 
the territory overcoming (deterritorialization) afforded by the globalization, since it would provide resources for all kinds of experiences of construction of the self, in any kind of societies and for all kind of people. The multiplicity of signs whether as news or as enjoyment and entertainment, raises the degree of aestheticization and performance, invades the political or familiar life, conjugating and complicating even more the notion of time and homogeneity.

This time the effect caused is probably of immediacy without precedents, but also of suspension of the notions of boundaries, space and territory, with the tendency, according to Appadurai, to association between seduction, cosmopolitanism and novelty, in which the electronic communications begin to "interrogate, subvert, and transform other contextual literacies" (2004: 14). The phenomenon of global communications, added to the one of international migrations, would complete the panorama of the main divisions of the contemporaneity, mentioned by Appadurai, who appeals to a fundamental ingredient of the subjective composition and responsible for the human action: the power of imagination. Not by chance, the imaginary about Brazil is recurrent in immigrants' reports that appealed to the soap operas and soccer as basis for the choice of migrating to the country. "I was Flamengo fan before I got here", reported a Congolese, or, "I always wanted to live in Copacabana", told an Angolan. Nowadays, these imaginaries are fed by the ICTs

More people than ever before seem to imagine routinely the possibility that they or their children will live and work in places other than where they were born: this is the wellspring of the increased rates of migration at every level of social, national and global life. [...] And then there are those who move in search of work, wealth, and opportunity often because their current circumstances are intolerable. [...] we may speak of diasporas of hope, diasporas of terror, and diasporas of despair. But in every case, these Diasporas bring the force of imagination, as both memory and desire, into the lives of many ordinary people, into mythographies different form the disciplines of myth and ritual of the classic sort. (Appadurai, 2004: 17)

Appadurai intends to call attention to the need to problematize the comprehension of the reasons that motivate the contemporary diasporas supported also by the imagination as a decisive factor to change residence. Thus, according Appadurai's proposal, although the migration, sponta- 


\section{From diaspora to ethnoscapes: diversity and belongingness in transnational migrations}

neous or forced, is not a recent phenomenon, it should be studied in the current context "juxtaposed with the rapid flow of mass-mediated images, scripts and sensations", and, then, promoted by "a mass-mediated imaginary that frequently transcends national space." (Ibid.: 18), what would enable the formation of "public spheres of diaspora." Although these spheres are situated within a territory, country, keep a dynamics of contact beyond the national territory, being a community of exchange and information within the fluid and dynamic space of the Internet, for instance.

The adoption of the neologism "ethnoscapes", elaborated by Appadurai, is justified from the concordance with his premise that the contemporary routine is made by the displacement of "tourists, immigrants, refugees, exiles, guest workers and other moving groups and individuals [...] and appear to affect the politics of (and between) to a hitherto unprecedented degree." (Ibid.: 51). Based on these arguments, we adopted the notion of transcultural ethnoscapes in order to try to understand how the public spheres of diaspora take shape in the cultural dynamics of cities' urban life. Or, as Hall points out (2000: 10):

Emerging cultures that feel threatened by the forces of globalization, diversity and hybridization or which have failed in the way in which the project of modernization is currently defined, may feel tempted to close down around their nationalist inscriptions and construct defensive walls against the outside. The alternative is not to cling to closed, unitary, homogenous models of 'cultural belonging' but to begin to learn to embrace the wider processes - the play of similarity and difference - which is transforming culture world-wide. This is the path of 'diaspora', which is the pathway of a modern people and a modern culture.

Thus, the proposal concerning the ethnoscapes starts from the assumption that there is need of adoption of new nomenclatures to try to understand the complexity of the relations between economy, culture and policy, that is, the mix of the different actors and their fields of activity: the Nation-States, the transnational companies, the communities of diaspora and the correlations with more traditional fields, as villages, boroughs, families, cities and countries. These multiple belongingnesses, local and global, start coexisting in spaces more and more diverse, where we are capable to cohabit, acknowledge and point out the difference, the otherness, in an intercultural entanglement. 


\section{FINAL CONSIDERATIONS}

Hall says (2003: 45):

Across the globe, the processes of so-called free and forced migrations are changing the composition, diversifying the cultures and pluralizing the cultural identities of the older dominant nation state, the old imperial powers, and indeed of the globe itself. The unregulated flows of peoples and cultures are as broad and as unstoppable as the sponsored flows of capital and technology. The former inaugurate a new process of 'minitorization' within the old metropolitan societies whose cultural homogeneity has long been silently assumed. But these 'minorities' are not effectively ghettoized; they do not long remain enclave settlements. They engage the dominant culture along a very broad front. They belong, in fact, to a transnational movement, and their connections are multiple and lateral. They mark the end of a 'modernity' defined exclusively in Western terms.

Let us decree, thus, the end of the occidental modern era. Should we decree, then, the end of the Euro-centered modern era? The people flows come from everywhere. If the globe has never been so easy to be taken, the distances have never been so diminished, the journeys, even extensive, complicated, expensive, are no longer insurmountable, the accesses to citizenship are increasingly difficult due to anti-immigrations laws. The people desire and imagine their lives due to the most diverse reasons and fight to accomplish their personal projects. The authorship of the own life is available to all. The migrants' narratives confirm that. Even those that flee war, who seek refuge, do not consider themselves as victims. They come to change the trajectory of their own lives. They seek to transform the world. However, the conditions for personal and safe accomplishment are more and more different from old questions that are back to light: ethnicity, origin country, material conditions, personal qualifications.

The international migrations are a reality in Europe, United States, in the North countries a lot longer than in the South countries. The latter lived diasporic realities, their emigrants sought in the developed countries chances of better life conditions, from work, study and personal development opportunities, to conditions of free subjective expression and points of view. With the closure of boundaries and the intensification of migratory controls, the flows South-South increased. The flows of people from poor countries to countries in development, more receptive and less strict in the institutional barriers to immigra- 


\section{From diaspora to ethnoscapes: diversity and belongingness in transnational migrations}

tion, become an alternative. It is in this context that we start receiving, even timidly, if we compare the Brazilian numbers with the ones from European countries, or even from some neighbors, like Argentina, for instance, migrant's flows from countries that have never composed the history of our migrations, like Bangladesh, Pakistan, Ghana, Haiti.

We are before a novelty and an opportunity. We may enrich ourselves with those presences. We can complexify our history, break a Eurocentric aesthetic, we can meet the Other, and dialogue with him/her. We can recreate localities from those global presences. We can break a granted homogeneity, mentioned by Hall, and, through the contact, the tension and imagination work, as emphasizes Appadurai, produce localities. Not by the mere hybridization of contents, of art, ideology, or technology, "but by the mutual negotiation and tension of contacts." For Appadurai, "localities are temporary negotiations between various globally circulating forms. They are not subordinate instances of the global, but in fact the main evidence of its reality." (2013: 69), for Hall, as aforementioned, this is the way of diaspora, that, in turn, starts being the way of "modern people in the modern world."

Due to our experience of researches of ethnoscapes in Brazilian cities, like the Kantuta Square in São Paulo, of Latin American migrants, the extinct Corredor da Central in Rio, of Ango-Congolese migrants, and, nowadays, due to the formation of emergent ethnoscapes, like in the outskirts of Brasilia, the Ghanaian and Pakistani migrants of Samabaia, we believe the meetings are fundamental for the opening to the Other. It is the square that becomes a place for enjoyment also for the Brazilian population in São Paulo, it is the Ghanaians' soccer game that is also played with the Brazilians in Samambaia. The meeting creates dialogue, but also resistance. The hypothesis is that the promotion of opportunities of cultural experience presents a diasporic room to the local population, with that, through plurality, a more cosmopolitan vision, or an intercultural meetings routine that amplifies the world vision and is acknowledge as a new behavior. The diasporic flows may become local realities, tension world visions, enlarge the understanding on History, and enrich the routine experience.

After all, as Cohen affirms "globalization and diasporization are separate phenomena with no necessary causal connections, but they 'go together' extraordinarily well” (2008: 154). With a world full of people running away from war and its consequences, from xenophobia, persecutions and poverty, lastly, for Hall, one institutes determined kind of globaliza- 
tion, which he calls informal, illegal, lateral globalization, and it becomes a counterpower.

Power will just tell them to stay where they are, so that capital can exploit the low cost of labor in the Third World. There is no point in the poor Pakistani moving to Los Angeles, where they would be required to pay 50 dollars a day. They pay them 2 dollars a day only if they stay where they are. The migration which has created this mix of cultures across the world, created multi-cultural cities, created new diasporas across the world, this is quite this is quite against the grain and logic of neoliberal globalization as such. (Hall, 2013: 206)

Therefore, Hall qualifies the diaspora as a critical concept in the political context of globalization. In this sense, he concludes: "And diasporas are [...] one of the cultural laboratories where the attempts of survival, the counter negotiations are going to be worked out." (2013: 207). It is this way, thus, that the diasporas represent a starting point of social and cultural transformations within the societies that live them, the beginning of new cultural landscapes. M

\section{REFERENCES}

APPADURAI, A. Dimensões culturais da globalização. Lisboa: Parábola, 2004.

. The future as a cultural fact: essays on the global condition. Nova York: Verso, 2013.

COHEN, R. Global diasporas: an introduction. Nova York: Routledge, 2008.

HALL, S. Cultural identity and diaspora. In: RUTHERFORD, J. (Ed.) Identity: community, culture, difference. Londres: Lawrence \& Wishart, 1990. p. 222-237.

Minimal selves. In: GRAY, A.; McGUIGAN, J. (Orgs.). Studying culture: an introductory reader. Londres: Edward Arnold, 1993. p. 134-138.

Diasporas or the cultural logics of translation. In: CONGRESSO DA ASSOCIAÇÃO BRASILEIRA DE LITERATURA COMPARADA, 7., 2000, Salvador/Bahia. Anais... Salvador: UFBA, 2000, 14 p. mimeo. 
Pensando a diáspora: reflexões sobre a terra no exterior. In: SOVIK, L. (Org.). Da diáspora: Identity and cultural mediations. Belo Horizonte: UFMG, 2003. p. 25-50.

. Entrevista com Stuart Hall: de Heloísa Buarque de Hollanda e Liv Sovik. Muiraquitã, Revista de Letras e Humanidades, Rio Branco, v. 2, n. 1, p. 196-207, jul./dez. 2013.

ZANFORIN, S. C. Etnicidade, migração e comunicação: etnopaisagens transculturais e negociação de pertencimentos. Tese (Doutorado em Comunicação e Cultura) - Universidade Federal do Rio de Janeiro, Rio de Janeiro, 2011.

Article received on March 17, 2015 and approved on May 25, 2016. 